postoperative graft infection must be considered and managed aggressively.

\footnotetext{
References

1. Stanson AW, Kazmier FJ, Hollier LH, Edwards WD, Pairolero PC, Sheedy PF, et al. Penetrating atherosclerotic ulcers of the thoracic aorta: natural history and
} clinicopathologic correlations. Ann Vasc Surg. 1986;1:15-23.
2. Troxler M, Mavor AI, Homer-Vanniasinkam S. Penetrating atherosclerotic ulcers of the aorta. Br J Surg. 2001;88:1169-77.

3. Coady MA, Rizzo JA, Hammond GL, Pierce JG, Kopf GS, Elefteriades JA. Penetrating ulcer of the thoracic aorta: What is it? How do we recognize it? How do we manage it? J Vasc Surg. 1998;27:1006-16.

4. Fukushima M, Seino Y, Yoshikawa M, Ueda Y, Takano T. A case of penetrating aortic atherosclerotic ulcer with hemoptysis. Jpn Heart J. 2000;41:781-5.

5. Raivio P, Suojaranta-Ylinen R, Kuitunen AH. Recombinant factor VIIa in the treatment of postoperative hemorrhage after cardiac surgery. Ann Thorac Surg. 2005; 80:66-71.

\title{
Concomitant cardiac and cerebral leiomyosarcoma: A challenge for surgical and adjuvant therapy
}

\author{
Christoph A. Tschan, MD, ${ }^{\mathrm{a}}$ M. Javad Mirzayan, MD, ${ }^{\mathrm{a}}$ Alexandru C. Stan, MD, ${ }^{\mathrm{b}}$ Maximilian A. Pichlmaier, MD, ${ }^{\mathrm{c}}$ and \\ Joachim K. Krauss, MD, ${ }^{a}$ Hannover, Germany
}

Primary sarcomas of the heart are rare, ${ }^{1}$ and features of leiomyosarcoma are present in only $1 \%$ to $9 \% .^{2}$ Although cardiac tumors, such as myxomas, occasionally can metastasize to the brain, this scenario is uncommon for leiomyosarcoma. Only 3 patients with leiomyosarcoma of the heart metastasizing to the brain have been reported within the past 40 years. $^{3-5}$ Here we report on a patient with the concomitant occurrence of a cerebral leiomyosarcoma and a cardiac leiomyosarcoma presenting initially with a generalized seizure. This is the first description of a patient in whom a cardiac leiomyosarcoma was detected only after diagnosis of the cerebral tumor.

\section{CLINICAL SUMMARY}

A 35-year-old man presented with a generalized seizure. A cranial magnetic resonance scan showed a large cystic right frontal tumor (Figure 1, $A$ and $B$ ). Diagnostic work-up raised the suspicion of a cardiac tumor. Magnetic resonance scans of the chest (Figure 1, $C$ and $D$ ) revealed an intracardiac neoplasm. Coronary angiographic and electrocardiographic analyses were without pathologic findings. Computed tomographic scanning of the whole body did not reveal any other tumor. First, the cardiac tumor was resected under extracorporeal circulation through a median sternotomy. The left

From the Department of Neurosurgery, ${ }^{\mathrm{a}}$ Institute of Pathology, ${ }^{\mathrm{b}}$ and Department of Cardiac, Thoracic, Transplantation and Vascular Surgery, ${ }^{c}$ Hannover Medical School, Hannover, Germany.

Received for publication April 8, 2008; revisions received May 8, 2008; accepted for publication May 21, 2008.

Address for reprints: Joachim K. Krauss, MD, Department of Neurosurgery, Hannover Medical School, Carl-Neuberg-Str. 1, D-30625 Hannover, Germany (E-mail: Krauss.Joachim@mh-hannover.de).

J Thorac Cardiovasc Surg 2009;137:e12-4

$0022-5223 / \$ 36.00$

Copyright (c) 2009 by The American Association for Thoracic Surgery doi:10.1016/j.jtcvs.2008.05.031 atrium was reconstructed with autogenic pericardium. Three weeks later, the frontal tumor was removed.

Both resected tumor specimens displayed characteristic histomorphologic features of a poorly differentiated leiomyosarcoma (Figure 1, $E$ and $F$ ). The immunohistochemical profile of the cardiac tumor was positive for $\alpha$-actin, smooth muscle actin, bcl-2, S-100, and CD117, with a Ki-67/MIB 1 proliferation index of $30 \%$. The cerebral tumor was positive for CD117 and vimentin, and a Ki-67/MIB 1 proliferation index of $40 \%$ was found.

Radiation therapy at 46 Gy was administered to the right frontal lobe. At 6 months of follow-up, imaging studies did not reveal residual tumors. Three months later, however, cerebral tumor recurrence was detected. The patient underwent a second craniotomy. Subsequent tumor staging revealed a spleen metastasis, followed by splenectomy. The tumor specimen demonstrated a capsular breakthrough and progression of dedifferentiation in terms of lack of expression of characteristic immunohistochemical markers.

Three months thereafter, another tumor recurrence occurred in the right frontal lobe. Whole-body staging showed widespread intra-abdominal metastases. A third craniotomy was performed. Chemotherapy was administered with doxorubicin and ifosfamide. Despite chemotherapy, the intracranial tumor recurred again. Therefore another course of radiation therapy was administered.

During adjuvant chemotherapy and radiotherapy, the frontal tumor progressed. With regard to the patient's good clinical condition, the decision was made to perform another craniotomy. Tumor staging at this time showed exploding intra-abdominal metastases. During the further course, catheter-induced sepsis developed. Laboratory examinations excluded HIV infection and other immunodeficiency syndromes. The patient died of septicemia 18 months after the primary diagnosis. 

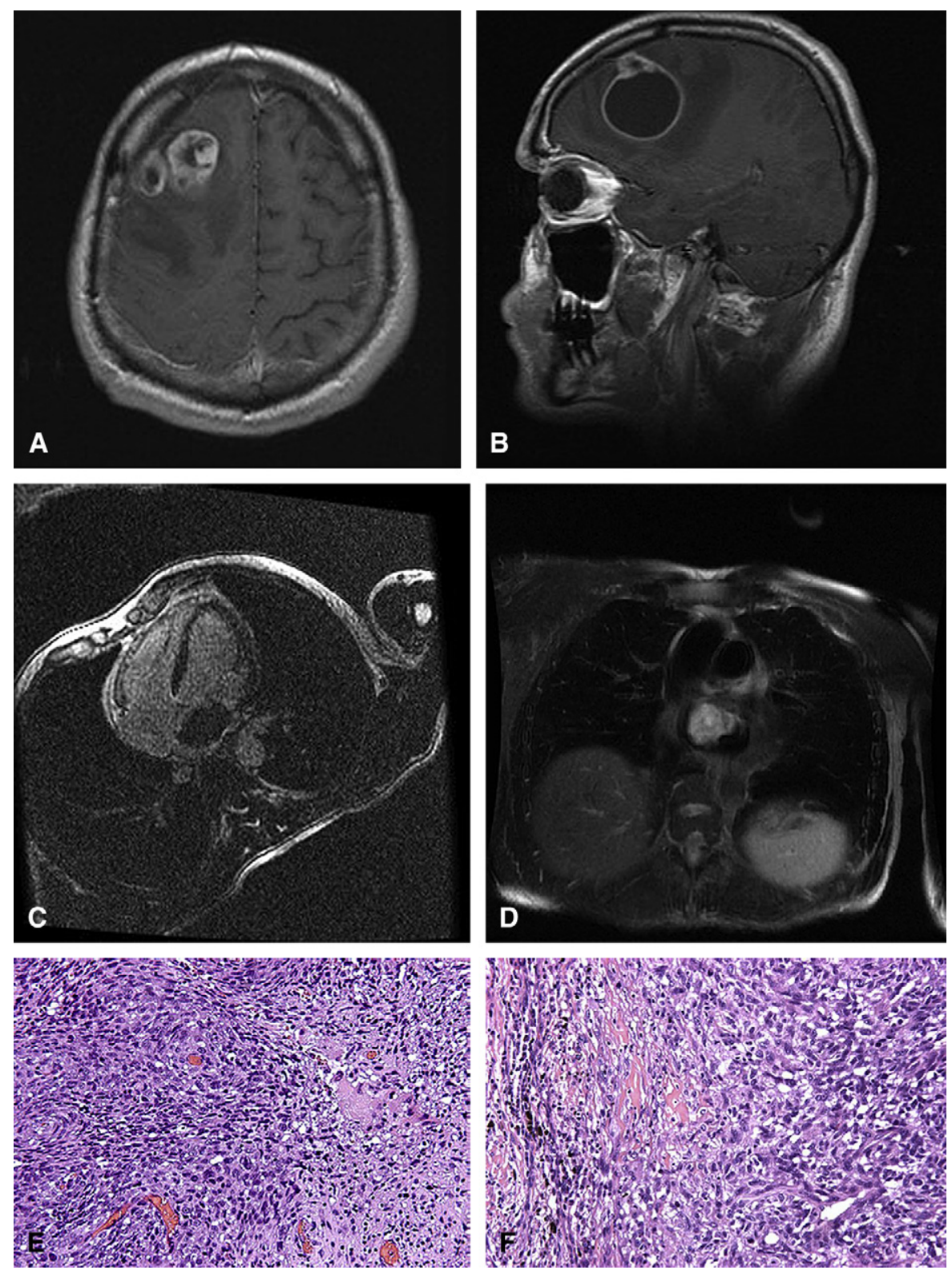

FIGURE 1. A and B, T1-weighted gadolinium-enhanced axial (A) and sagittal (B) magnetic resonance scans show a large cystic right frontal tumor with an enhancing nodule in its upper aspect accompanied by marked edema. C, T1-weighted gadolinium-enhanced magnetic resonance scan of the chest: 4-chamber view localizes the tumor in the left atrium. D, Fat-suppressed T2-weighted magnetic resonance scan shows the cardiac tumor nearly filling the left atrium. E and F, Histopathologic features of the cardiac (E) and cerebral (F) tumors. Hematoxylin and eosin-stained specimens of both tumors show similar features of a poorly differentiated leiomyosarcoma $\mathrm{G} 3$. (Original magnification $\times 100$.)

\section{DISCUSSION}

The largest consecutive postmortem study reported by the American Medical Association found the prevalence of primary cardiac tumors to be only $0.0017 \%{ }^{6}$ Approximately $25 \%$ of primary cardiac tumors in adults are malignant, and most of them are sarcomas. In exceptional cases cardiac sarcomas can metastasize to the brain. Leiomyosarcomas of the heart are very rare, accounting for only $0.25 \%$ of all cardiac tumors. ${ }^{1}$ In the 3 instances ${ }^{3-5}$ of cardiac leiomyosarcoma metastasizing to the brain reported previously, the cardiac tumor was the primary clinical manifestation, and the brain metastasis appeared only secondarily (Table 1).

For reasons unknown, leiomyosarcomas, in general, appear to metastasize only exceptionally to the central nervous system. In a cohort of 3829 patients with soft tissue sarcomas, only 8 patients had a leiomyosarcoma metastatic to the brain. ${ }^{7}$ On the other hand, primary intracranial leiomyosarcomas are even rarer. In an overview on 25,000 brain tumor biopsy specimens, 3 cases were reported to be a primary cerebral leiomyosarcoma. ${ }^{8}$ 
TABLE 1. Cardiac leiomyosarcoma metastasizing to the brain: Literature review

\begin{tabular}{|c|c|c|c|c|c|c|c|c|}
\hline References & $\begin{array}{c}\text { Age } \\
(y) / \text { sex }\end{array}$ & $\begin{array}{c}\text { Initial } \\
\text { symptoms }\end{array}$ & $\begin{array}{l}\text { Primary } \\
\text { tumor }\end{array}$ & Surgical procedure & Adjuvant therapy & $\begin{array}{c}\text { Brain } \\
\text { metastasis }\end{array}$ & $\begin{array}{c}\text { Other } \\
\text { metastasis }\end{array}$ & $\begin{array}{c}\text { Survival } \\
\text { time } \\
\end{array}$ \\
\hline $\begin{array}{l}\text { Babatasi and } \\
\text { coworkers, }{ }^{3} \\
1998\end{array}$ & 47 , male & $\begin{array}{l}\text { Weight loss, } \\
\text { pulmonary } \\
\text { edema }\end{array}$ & Left atrium & $\begin{array}{l}\text { Resection of the left } \\
\text { atrial mass } \\
\text { orthotopic } \\
\text { heart } \\
\text { transplantation } \\
\text { after } 6 \text { mo }\end{array}$ & None & $\begin{array}{l}15 \text { mo } \\
\text { later }\end{array}$ & Liver, bone & $15 \mathrm{mo}$ \\
\hline $\begin{array}{l}\text { Thomas and } \\
\text { coworkers, } \\
1992\end{array}$ & 37 , male & $\begin{array}{l}\text { Polyarthralgia, } \\
\text { fever, dyspnea }\end{array}$ & Left atrium & $\begin{array}{l}\text { Resection of the } \\
\text { atrial mass, } \\
\text { resection } \\
\text { of brain } \\
\text { metastasis, } \\
\text { partial bowel } \\
\text { resection }\end{array}$ & $\begin{array}{l}\text { Mediastinal } \\
\text { radiotherapy plus } \\
\text { Chemotherapy, } \\
\text { (whole-brain and } \\
\text { local boost) }\end{array}$ & $\begin{array}{l}14 \text { mo } \\
\text { later }\end{array}$ & $\begin{array}{l}17 \text { mo later, } \\
\text { multiple } \\
\text { sites }\end{array}$ & $17 \mathrm{mo}$ \\
\hline Cohen, ${ }^{5} 1969$ & 41 , male & $\begin{array}{l}\text { Hemoptysis, } \\
\text { chest pain, } \\
\text { headache }\end{array}$ & $\begin{array}{l}\text { Right and left } \\
\text { atrium plus } \\
\text { bowel }\end{array}$ & $\begin{array}{l}\text { Resection of the } \\
\text { cardiac } \\
\text { tumor, cardiac } \\
\text { reoperation }\end{array}$ & None & $\begin{array}{l}\text { Autopsy } \\
\text { finding }\end{array}$ & $\begin{array}{l}\text { Autopsy } \\
\text { finding, } \\
\text { multiple } \\
\text { sites }\end{array}$ & $17 \mathrm{mo}$ \\
\hline
\end{tabular}

Our patient is unique with regard to the concomitant manifestation of the cerebral and cardiac leiomyosarcomas. Most likely, the cerebral manifestation should be regarded as a metastasis; the immunohistochemical profiles and the clinical history, however, also allow different interpretations.

The best available therapy for undifferentiated leiomyosarcoma consists of early detection and radical surgical removal. Although the cardiac tumor in our patient showed no relapse after complete removal, the cerebral tumor recurred several times. The repeated craniotomies within short intervals can be discussed controversially. Nevertheless, because the patient was asymptomatic apart from occasional seizures, we decided to offer him these options as live-saving procedures.

Concomitant cardiac and cranial leiomyosarcoma seems to be particularly aggressive, and only diligent follow-up examinations and early surgical intervention will make long- term survival possible. There is a need for more efficacious adjuvant therapy.

\section{References}

1. Antunes MJ, Vanderdonck KM, Andrade CM, Rebelo LS. Primary cardiac leiomyosarcomas. Ann Thorac Surg. 1991;51:999-1001.

2. Butany J, Nair V, Naseemuddin A, Nair GM, Catton C, Yau T. Cardiac tumors: diagnosis and management. Lancet Oncol. 2005;6:219-28.

3. Babatasi G, Massetti D, Agostini F, Galateau F, Le Page O, Saloux E, et al. Leiomyosarcomas of the heart and great vessels. Ann Cardiol Angiol. 1998; 47:451-8.

4. Thomas CR Jr, Johnson GW Jr, Stoddard MF, Clifford S. Primary malignant cardiac tumors: update 1992. Med Pediatr Oncol. 1992;20:519-31.

5. Cohen ML. Intracardiac leiomyosarcoma. N Y State J Med. 1969;69:1767-72.

6. Straus R, Merliss R. Primary tumor of the heart. Arch Pathol Lab Med. 1945;39: 74-8.

7. Espat NJ, Bilsky M, Lewis JJ, Leung D, Brennan MF. Soft tissue sarcoma brain metastases: prevalence in a cohort of 3829 patients. Cancer. 2002;94:2706-11.

8. Paulus W, Slowik F, Jellinger K. Primary intracranial sarcomas: histopathological features of 19 cases. Histopathology. 1991;18:395-402.

\section{Cardiac echinococcosis of the interventricular septum in early childhood: Report of two cases}

T. Mohsen, MD, FRCS, N. El Beharry, MD, T. Maree, MD, and E. S. Akl, MD, Cairo, Egypt

\author{
From the Department of Cardiothoracic Surgery, Kasr El Aini Hospital, Cairo \\ University, Cairo, Egypt. \\ Received for publication April 2, 2008; accepted for publication April 16, 2008. \\ Address for reprints: T. Mohsen, MD, FRCS, Kasr El Aini Hospital, Cairo University \\ Cardiothoracic Surgery, Villa 23 street 262 New Maadi, Cairo11431 Egypt (E-mail: \\ tmohsen_2000@yahoo.com). \\ J Thorac Cardiovasc Surg 2009;137:e14-6 \\ 0022-5223/\$36.00 \\ Copyright (c) 2009 by The American Association for Thoracic Surgery \\ doi:10.1016/j.jtcvs.2008.04.008
}

Echinococcosis has a low endemicity in Egypt. However, in some governorates it presents a public health concern with an incidence ranging from 0.8 to 2.6 per $100,000 .^{1}$ Cardiac infestation is very uncommon, accounting for $0.5 \%$ to $2 \%$ of all hydatid infestations. ${ }^{2}$ We present 2 cases of hydatid cysts of the interventricular septum in early childhood. 